\title{
High quality draft genome sequence of Streptomyces sp. strain AW19M42 isolated from a sea squirt in Northem Norway
}

\author{
Gro Elin Kjæreng Bjerga ${ }^{1}$, Erik Hjerde ${ }^{1}$, Concetta De Santi ${ }^{1}{ }^{2}$, Adele Kim Williamson ${ }^{1}$, Arne \\ Oskar Smalås ${ }^{1}$, Nils Peder Willassen ${ }^{1}$, Bjørn Altermark ${ }^{1}$ \\ ${ }^{1}$ Norstruct, Department of Chemistry, Faculty of Science and Technology, University of \\ Tromsø, Norway \\ ${ }^{2}$ Institute of Protein Biochemistry, National Research Council, Naples, Italy \\ Correspondence: (Bjørn Altermark) bjorn.altermark@uit.no
}

Keywords: Bioprospecting, enzymes, metabolites, Streptomyces, Actinobacteria

\begin{abstract}
Here we report the $8 \mathrm{Mb}$ high quality draft genome of Streptomyces sp. strain AW19M42, together with specific properties of the organism and the generation, annotation and analysis of its genome sequence. The genome encodes 7,727 putative open reading frames, of which 6,400 could be assigned with COG categories. Also, 62 tRNA genes and 8 rRNA operons were identified. The genome harbors several gene clusters involved in the production of secondary metabolites. Functional screening of the isolate was positive for several enzymatic activities, and some candidate genes coding for those activities are listed in this report. We find that this isolate shows biotechnological potential and is an interesting target for bioprospecting.
\end{abstract}

\section{Introduction}

The filamentous and Gram-positive genus Streptomyces, belonging to the phylum Actinobacteria [1], are attractive organisms for bioprospecting being the largest antibiotic-producing genus discovered in the microbial world so far [2]. These species have also been exploited for heterologous expression of a variety of secondary metabolites [3]. Additionally, these species harbor genes coding for enzymes that can be applicable in industry and biotechnology $[4,5]$.

Since the first, complete Streptomycesgenome was published [6], a number of strains isolated from terrestrial environments have been reported [711]. Genomic investigations on Streptomycesfrom marine sources have, however, just recently begun [12-16].

Here, we present the draft genome sequence of Streptomyces $s p$. strain AW19M42 isolated from a marine source, together with the description of genome properties and annotation. Results from functional enzyme screening of the bacterium are also reported.

\section{Classification and features}

The Streptomyces sp. strain AW19M42 was identified in a biota sample collected from the internal organs of a sea squirt (class Ascidiacea, subphylum Tunicate, phylum Chordata). The tunicate was isolated using an Agassiz trawl at a depth of $77 \mathrm{~m}$ in Hellmofjorden, in the sub-Arctic region of Norway (Table 1). The trawling was done during a research cruise with R/V Jan Mayen in April 2010.

The bacterium was isolated during four weeks of incubation at $4-15^{\circ} \mathrm{C}$ on humic acid containing agar media that is selective for growth of actinomycetes [29,30]. For isolation and nucleic acid extraction the bacterium was cultivated in autoclaved media containing $0.1 \%(\mathrm{w} / \mathrm{v})$ malt extract, $0.1 \%(\mathrm{v} / \mathrm{v})$ glycerol, $0.1 \%(\mathrm{w} / \mathrm{v})$ peptone, $0.1 \%(\mathrm{w} / \mathrm{v})$ yeast extract, $2 \%(\mathrm{w} / \mathrm{v})$ agar in $50 \%$ $(\mathrm{v} / \mathrm{v})$ natural sea water and $50 \%(\mathrm{v} / \mathrm{v})$ distilled water, pH 8.2 [29]. The gene encoding16S rRNA was amplified by using two universal primers, 27F (5'-AGAGTTTGATCCTGGCTCAG) and 1492R (5'GGTTACCTTGTTACGACTT) [31], in a standard Taq polymerase driven PCR (VWR) on crude genomic DNA prepared by using InstaGene Matrix (BioRad). Following PCR purification by PureLink PCR Purification (Invitrogen), sequencing was 
carried out with the BigDye terminator kit version 3.1 (Applied Biosystems) and a universal 515F primer (5'-GTGCCAGCMGCCGCGGTAA) [32]. Using the 16S rRNA sequence data in a homology search by BLAST [33] indicated that the isolate belonged to the Streptomycesgenus, among the Streptomycetaceaefamily of Actinobacteria. A phylogenetic tree was reconstructed from the $16 \mathrm{~S}$ rRNA gene sequence together with other Streptomyceshomologues (Figure 1) using the MEGA 5.10 software suit [34]. The evolutionary history was inferred using the UPGMA method [35] and the evolutionary distances were computed using the Maximum Composite Likelihood method [36]. The phylogenetic analysis confirmed that the isolate AW19M42 belongs to the genus Streptomyces. The closest neighbor with a reported, complete genome sequence is Streptomyces griseus subsp. griseus [7], however, the phylogenetic tree indicates that the Streptomyces sp. strain AW19M42 isolate belongs to a closely related but separate clade. Draft genomes have not been reported for this clade previously.

Table 1. Classification and general features of Streptomyces sp. strain AW19M42 according to the MIGS recommendations [17]

\begin{tabular}{|c|c|c|c|}
\hline MIGS ID & Property & Term & Evidence code \\
\hline & \multirow{10}{*}{ Current classification } & Domain Bacteria & TAS [18] \\
\hline & & Phylum Actinobacteria & TAS [1] \\
\hline & & Class Actinobacteria & TAS [19] \\
\hline & & Subclass Actinobacteridae & TAS $[19,20]$ \\
\hline & & Order Actinomycetales & TAS [19-22] \\
\hline & & Suborder Streptomycineae & TAS $[19,20]$ \\
\hline & & Family Streptomycetaceae & TAS $[19,20,22-24]$ \\
\hline & & Genus Streptomyces & TAS $[22,24-27]$ \\
\hline & & Species Streptomyces sp. & NAS \\
\hline & & Strain AW19M42 & IDA \\
\hline & Gram stain & Gram positive & NDA \\
\hline & Cell shape & Branched mycelia & NDA \\
\hline & Motility & Dispersion of spores & NDA \\
\hline & Sporulation & Sporulating & NDA \\
\hline & Temperature range & Range not determined, grows at $15^{\circ} \mathrm{C}$ and $28^{\circ} \mathrm{C}$ & IDA \\
\hline MIGS-6.3 & Salinity & Not determined, but survives $50 \%$ natural sea water & IDA \\
\hline \multirow[t]{3}{*}{ MIGS-22 } & Oxygen requirements & Aerobic & NDA \\
\hline & Carbon source & Not reported & \\
\hline & Energy source & Not reported & \\
\hline MIGS-6 & Habitat & Inner organs of sea squirt & IDA \\
\hline MIGS-15 & Biotic relationship & Free-living & IDA \\
\hline \multirow[t]{2}{*}{ MIGS-14 } & Pathog enicity & Non-pathogenic & NDA \\
\hline & Biosafety level & 1 & \\
\hline MIGS-4 & Geographic location & Hellmofjorden, Norway & IDA \\
\hline MIGS-5 & Sample collection time & April 2010 & IDA \\
\hline MIGS-4.1 & Latitude & N67 49.24316 & IDA \\
\hline MIGS-4.2 & Long itude & E16 28.99465 & IDA \\
\hline MIGS-4.3 & Depth & $77.35 \mathrm{~m}$ & IDA \\
\hline
\end{tabular}

Evidence codes - IDA: Inferred from Direct Assay (first time in publication); TAS: Traceable Author Statement (i.e., a direct report exists in the literature); NAS: Non-traceable Author Statement (i.e., not directly observed for the living, isolated sample, but based on a generally accepted property for the species, or anecdotal evidence). These evidence codes are from of the Gene Ontology project [28]. If the evidence code is IDA, then the property was directly observed for a live isolate by one of the authors or an expert or mentioned in the acknowledgements. 
The bacterium was isolated during four weeks of incubation at $4-15^{\circ} \mathrm{C}$ on humic acid containing agar media that is selective for growth of actinomycetes $[29,30]$. For isolation and nucleic acid extraction the bacterium was cultivated in autoclaved media containing $0.1 \%(\mathrm{w} / \mathrm{v})$ malt extract, $0.1 \%(\mathrm{v} / \mathrm{v})$ glycerol, $0.1 \%(\mathrm{w} / \mathrm{v})$ peptone, $0.1 \%(\mathrm{w} / \mathrm{v})$ yeast extract, $2 \%$ $(\mathrm{w} / \mathrm{v})$ agar in $50 \%(\mathrm{v} / \mathrm{v})$ natural sea water and $50 \%$ ( $\mathrm{v} / \mathrm{v})$ distilled water, $\mathrm{pH} 8.2$ [29]. The gene encoding16S rRNA was amplified by using two universal primers, 27F ( $5^{\prime}$-AGAGTTTGATCCTGGCTCAG) and 1492R (5'-GGTTACCTTGTTACGACTT) [31], in a standard Taq polymerase driven PCR (VWR) on crude genomic DNA prepared by using InstaGene Matrix (BioRad). Following PCR purification by PureLink PCR Purification (Invitrogen), sequencing was carried out with the BigDye terminator kit version 3.1 (Applied Biosystems) and a universal 515F primer (5'-GTGCCAGCMGCCGCGGTAA) [32]. Using the 16S rRNA sequence data in a homology search by BLAST [33] indicated that the isolate belonged to the Streptomycesgenus, among the Streptomycetaceaefamily of Actinobacteria. A phylogenetic tree was reconstructed from the 16S rRNA gene sequence together with other Streptomyceshomologues (Figure 1) using the MEGA 5.10 software suit [34]. The evolutionary history was inferred using the UPGMA method [35] and the evolutionary distances were computed using the Maximum Composite Likelihood method [36]. The phylogenetic analysis confirmed that the isolate AW19M42 belongs to the genus Streptomyces. The closest neighbor with a reported, complete genome sequence is Streptomyces griseus subsp. griseus [7], however, the phylogenetic tree indicates that the Streptomyces sp. strain AW19M42 isolate belongs to a closely related but separate clade. Draft genomes have not been reported for this clade previously.

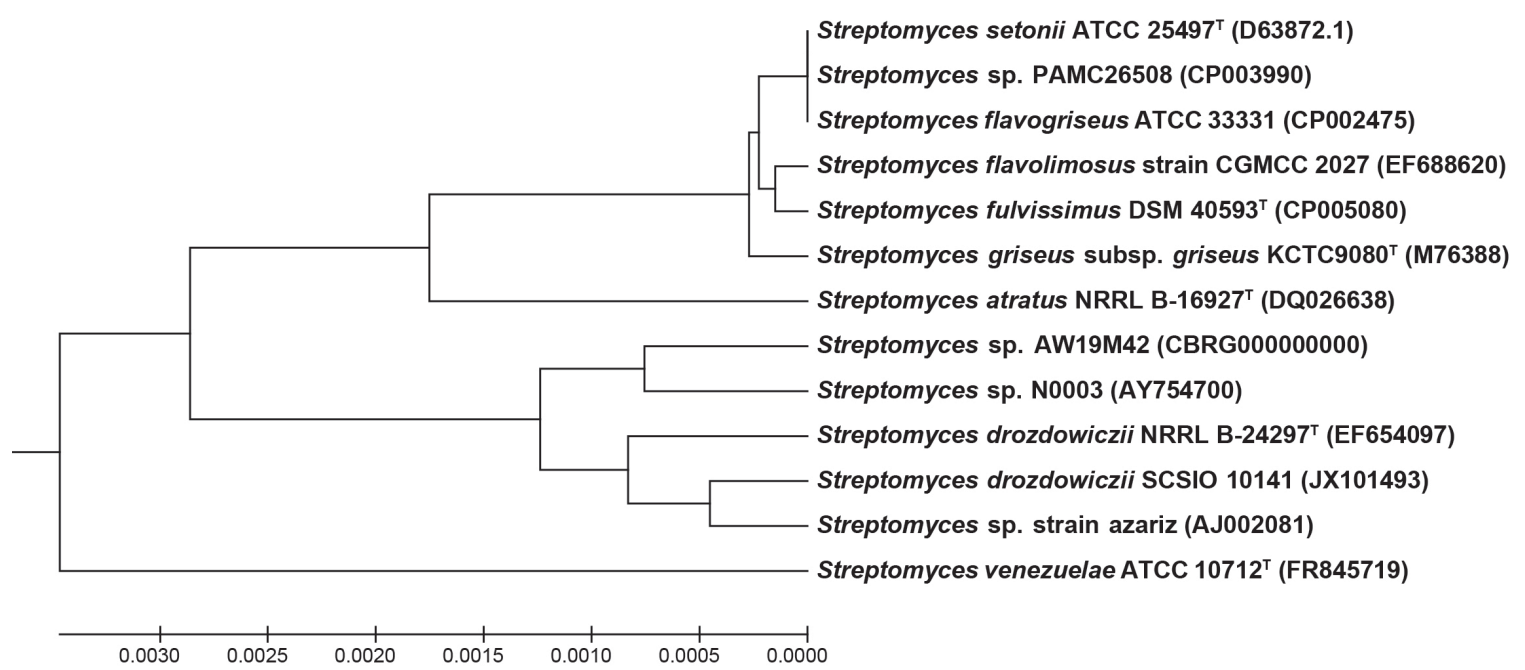

Figure 1. Phylogenetic tree indicating the phylogenetic relationship of Streptomyces sp. strain AW19M42 relative to other Streptomycesspecies. The phylogenetic tree was made by comparing the $16 \mathrm{~S}$ rDNA sequence of the Streptomyces sp. strain AW19M42 to the closest related sequences from both validated type strains and unidentified isolates. S. venezuelea is used as outgroup. All positions containing gaps and missing data were eliminated. There were a total of 1,389 positions in the final dataset. The bar shows the number of base substitutions per site.

\section{Genome sequencing and annotation}

The organism was selected for genome sequencing on the basis of its phylogenetic position. The genome project is part of a Norwegian bioprospecting project called Molecules for the Future (MARZymes) which aims to search Arctic and sub-Arctic regions for marine bacterial isolates that might serve as producers of novel secondary metabolites and enzymes. High quality genomic DNA for sequencing was isolated with the GenElute Bacterial Genomic DNA Kit (Sigma) according to the protocol for ex- traction of nucleic acids from gram positive bacteria. A 700 bp paired-end library was prepared and sequenced using the HiSeq 2000 (Illumina) pairedend technology (Table 2). This generated 13.94 million paired-end reads that were assembled into 670 contigs larger than 500 bp using the CLC Genomics Workbench 5.0 software package [37]. Gene prediction was performed using Glimmer 3 [38] and gene functions were annotated using an in-house genome annotation pipeline. 


\section{Genome properties}

The total size of the genome is $8,008,851 \mathrm{bp}$ and has a GC content of $70.57 \%$ (Table 3), similar to that of other sequenced Streptomycesisolates. A total of 7,727 coding DNA sequences (CDSs) were predicted (Table 3 ). Of these, 6,400 could be assigned to a COG number (Table 4). In addition, 62 tRNAs and 8 copies of the rRNA operons were identified.

Table 2. Genome sequencing project information

\begin{tabular}{lll}
\hline MIGS ID & Property & Term \\
\hline MIGS-31 & Finishing quality & Improved high quality draft \\
MIGS-28 & Libraries used & One Illumina Paired-End library \\
MIGS-29 & Sequencing platforms & Illumina HiSeq2000 \\
MIGS-31.2 & Fold coverage & $350 \times$ \\
MIGS-30 & Assemblers & CLC paired-end assembly \\
MIGS-32 & Gene calling method & Glimmer 3 \\
& Genbank ID & CBRG000000000 \\
& Genbank Date of Release & September 11, 2013 \\
& GOLD ID & Gi0070794 \\
& Project relevance & Bioprospecting \\
\hline
\end{tabular}

Table 3. Genome statistics, including nucleotide content and gene count levels

\begin{tabular}{lcr}
\hline Attribute & Value & \% of total \\
\hline Genome size (bp) & $8,008,851$ & 100 \\
DNA coding region (bp) & $6,979,999$ & 87.2 \\
DNA G+C content (bp) & $4,951,797$ & $\mathrm{n} / \mathrm{a}$ \\
Total genes & 7,813 & $\mathrm{n} / \mathrm{a}$ \\
rRNA operons & 8 & $\mathrm{n} / \mathrm{a}$ \\
tRNA genes & 62 & 100 \\
Protein-coding genes & 7,727 & 82.8 \\
Genes assigned to COGs & 6,400 & 12.8 \\
Genes with signal peptides & 987 & 21.5 \\
Genes with transmembrane helices & 1,660 & \\
\hline
\end{tabular}

The total is based on either the size of the genome in base pairs or the total number of protein coding genes in the annotated genome. 
Table 4. Number of genes associated with the 25 general COG functional categ ories

Code Value \%age ${ }^{\mathrm{a}}$ Description

\begin{tabular}{|c|c|c|}
\hline J & 264 & 3.4 Translation \\
\hline A & 1 & 0.0 RNA processing and modification \\
\hline K & 836 & 10.8 Transcription \\
\hline $\mathrm{L}$ & 330 & 4.3 Replication, recombination and repair \\
\hline B & 5 & 0.1 Chromatin structure and dynamics \\
\hline $\mathrm{D}$ & 71 & 0.9 Cell cycle control, mitosis and meiosis \\
\hline Y & 0 & 0.0 Nuclear structure \\
\hline $\mathrm{V}$ & 159 & 2.1 Defense mechanisms \\
\hline $\mathrm{T}$ & 442 & 5.7 Signal transduction mechanisms \\
\hline M & 338 & 4.3 Cell wall/membrane biog enesis \\
\hline N & 28 & 0.4 Cell motility \\
\hline Z & 6 & 0.1 Cytoskeleton \\
\hline W & 0 & 0.0 Extracellular structures \\
\hline U & 79 & 1.0 Intracellular trafficking and secretion \\
\hline $\mathrm{O}$ & 200 & 2.6 Posttranslational modification, protein turnover, chaperones \\
\hline $\mathrm{C}$ & 409 & 5.3 Energy production and conversion \\
\hline G & 665 & 8.6 Carbohydrate transport and metabolism \\
\hline E & 730 & 9.4 Amino acid transport and metabolism \\
\hline $\mathrm{F}$ & 123 & 1.6 Nucleotide transport and metabolism \\
\hline $\mathrm{H}$ & 262 & 3.4 Coenzyme transport and metabolism \\
\hline I & 330 & 4.3 Lipid transport and metabolism \\
\hline $\mathrm{P}$ & 435 & 5.6 Inorg anic ion transport and metabolism \\
\hline Q & 417 & 5.4 Secondary metabolites biosynthesis, transport and catabolism \\
\hline $\mathrm{R}$ & 1,181 & 15.3 General function prediction only \\
\hline S & 465 & 6.0 Function unknown \\
\hline - & 1,327 & 17.2 Not in COGs \\
\hline
\end{tabular}

aThe total is based on the total number of protein coding genes in the annotated genome. 
All putative protein coding sequences were assigned KEGG orthology [39], and mapped onto pathways using the KEGG Automatic Annotation Server (KAAS) server [40]. The analysis revealed that Streptomyces sp. strain AW19M42 harbors several genes related to biosynthesis of secondary metabolites. We have identified genes that map to the streptomycin biosynthesis pathway (glucose-1-phosphate thymidylyltransferase (EC 2.7.7.24), dTDP-glucose 4,6-dehydratase (EC 4.2.1.46) and dTDP-4-dehydrorhamnose reductase (EC 1.1.1.133)). Also, several genes map to the pathways for biosynthesis of siderophore group nonribosomal peptides, biosynthesis of type II polyketide product pathway and polyketide sugar unit biosynthesis. Interestingly, two clusters, comprising five genes, both mapped to the biosynthesis of type II polyketide backbone pathway. These genes clusters comprise genes STREP_3146-3150 and STREP_4370-
4374. This suite of genes may contribute to a distinct profile of secondary metabolites production.

\section{Insights from the Genome Sequence}

The isolate was successfully screened for lipase, caseinase, gelatinase, chitinase, amylase and DNase activities (Figure 2), by using marine broth (Difco) agar plates incubated at $20^{\circ} \mathrm{C}$ [41-46]. The plates were supplemented with $1 \% \quad(\mathrm{v} / \mathrm{v})$ tributyrin, $1 \%(\mathrm{w} / \mathrm{v})$ skim milk, $0.4 \%(\mathrm{w} / \mathrm{v})$ gelatin, $0.5 \%(\mathrm{w} / \mathrm{v})$ chitin or $2 \%(\mathrm{w} / \mathrm{v})$ starch, respectively (all substrates from Sigma), whereas DNase test agar (Merck) was supplemented with $0.3 \mathrm{M}$ $\mathrm{NaCl}$, representing sea water salt concentration, before screening for DNase activity. Putative genes coding for these activities were identified in the genome based on annotation or by homology search (Table 5).
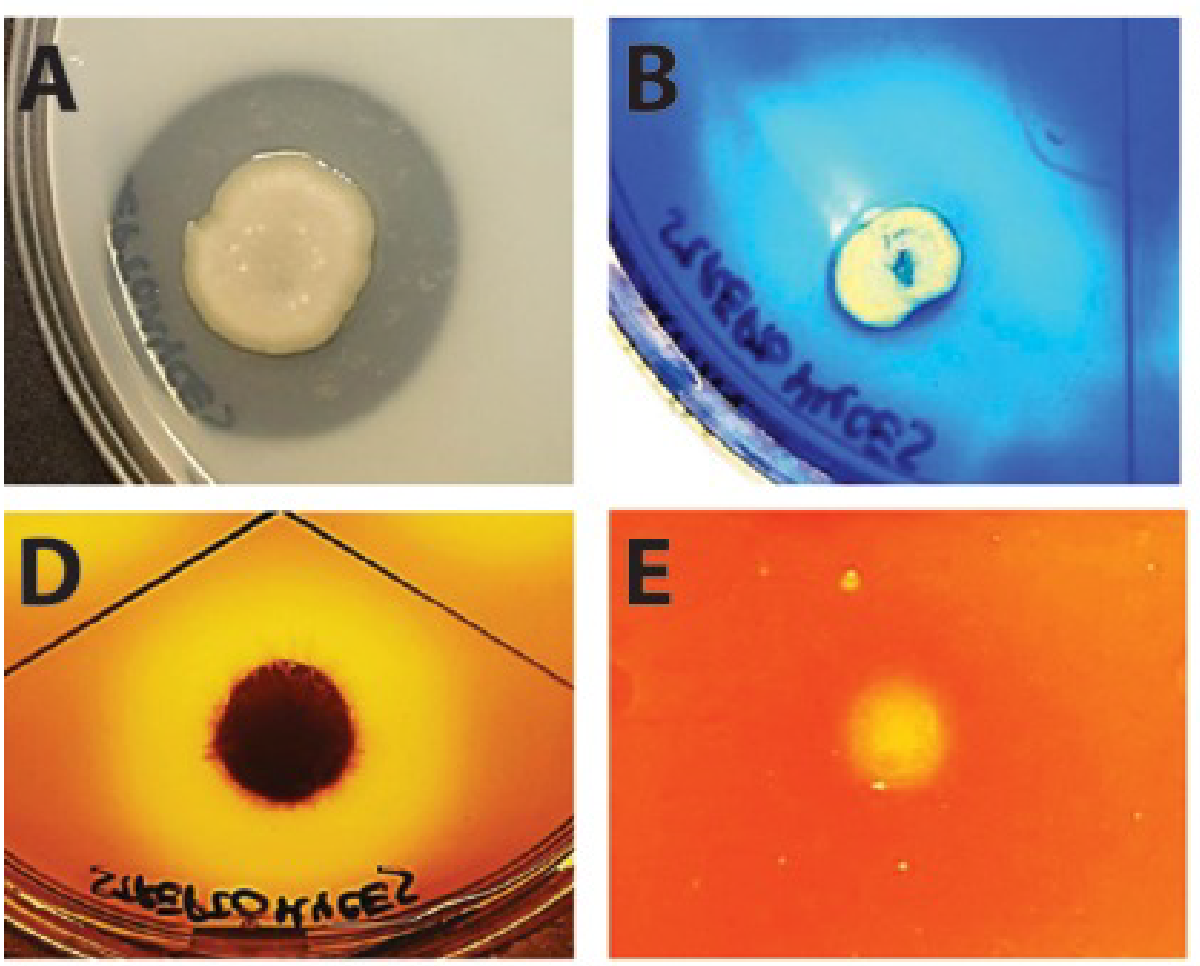
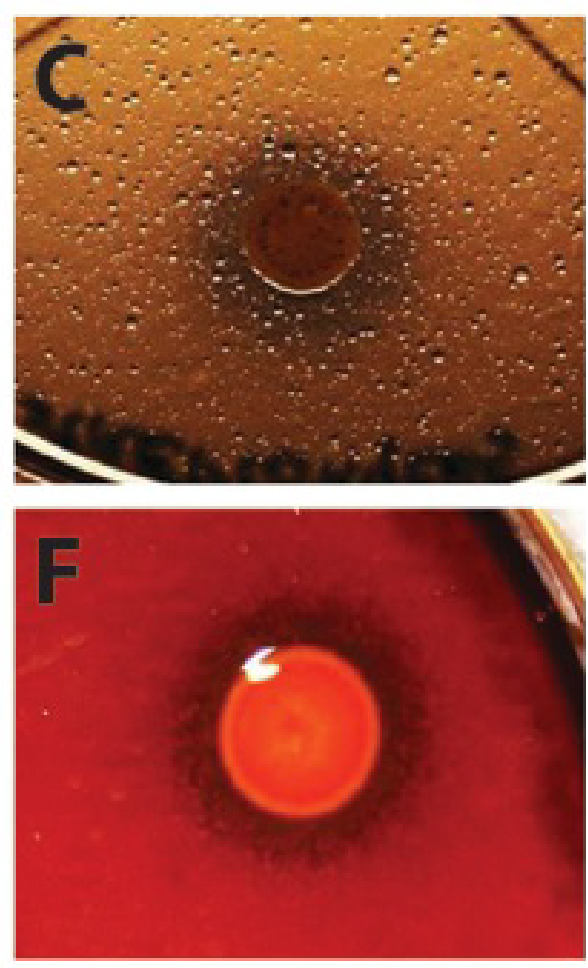

Figure 2. Degradation halos around colonies of Streptomyces sp. AW19M42 growing on agar plates supplemented with A, skim milk, B, gelatin, C, tributyrin, D, DNA, E, chitin and F, starch. 
Table 5. Candidate genes coding for putative lipase, caseinase, gelatinase and DNase activities identified in Streptomyces sp. strain AW19M42 draft genome.

\begin{tabular}{|c|c|c|}
\hline Putative gene & Annotation & Size (aa) \\
\hline \multicolumn{3}{|l|}{ Lipase } \\
\hline STREP_0737 & Lipase & 273 \\
\hline STREP_1671 & Triacylglycerol lipase & 266 \\
\hline STREP_1821 & G-D-S-L family lipolytic protein & 281 \\
\hline STREP_2698 & Lipase class 2 & 297 \\
\hline STREP_2704 & Triacylglycerol lipase & 269 \\
\hline STREP_4585 & Secreted hydrolase & 268 \\
\hline STREP_5662 & Lipase or acylhydrolase family protein & 367 \\
\hline STREP_6665 & Esterase/lipase & 259 \\
\hline STREP_6850 & Esterase/lipase & 429 \\
\hline STREP_7611 & Triacylglycerol lipase & 366 \\
\hline \multicolumn{3}{|l|}{ Gelatinase } \\
\hline STREP_5784 & Peptidase M4 thermolysin & 523 \\
\hline STREP_6038 & Peptidase M4 thermolysin & 680 \\
\hline STREP_3662 & Peptidase M4 thermolysin & 358 \\
\hline \multicolumn{3}{|l|}{ Caseinase } \\
\hline STREP_0198 & Putative secreted serine protease & 361 \\
\hline STREP_0258 & Protease & 278 \\
\hline STREP_0974 & Protease & 488 \\
\hline STREP_1078 & Serine protease & 388 \\
\hline STREP_1313 & M6 family metalloprotease domain-containing protein & 398 \\
\hline STREP_1389 & M6 family metalloprotease domain protein & 1,389 \\
\hline STREP_2216 & Putative secreted subtilisin-like serine protease & 511 \\
\hline STREP_2239 & metalloprotease & 296 \\
\hline STREP_3135 & Metalloprotease domain protein & 127 \\
\hline STREP_3964 & ATP-dependent protease La & 808 \\
\hline STREP_3975 & ATP-dependent metalloprotease Fts H & 673 \\
\hline STREP_4000 & Streptog risin-B - Pronase enzyme B SGPB/Serine protease B & 299 \\
\hline STREP_5179 & ATP-dependent Clp protease proteolytic subunit & 222 \\
\hline STREP_5180 & ATP-dependent Clp protease, ATP-binding subunit ClpX & 432 \\
\hline STREP_5944 & Protease & 527 \\
\hline STREP_5945 & Protease & 534 \\
\hline STREP_6196 & Protease & 383 \\
\hline STREP_6570 & Protease & 701 \\
\hline STREP_6821 & Putative protease & 352 \\
\hline STREP_7179 & Serine protease & 635 \\
\hline STREP_7580 & Protease & 856 \\
\hline \multicolumn{3}{|l|}{ DNase } \\
\hline STREP_0436 & Exodeoxyribonuclease VII, large subunit & 403 \\
\hline STREP_0437 & Exodeoxyribonuclease VII small subunit & 91 \\
\hline STREP_1352 & Exodeoxyribonuclease III Xth & 268 \\
\hline STREP_1969 & TatD-related deoxyribonuclease & 1,969 \\
\hline STREP_2155 & Deoxyribonuclease $\mathrm{V}$ & 220 \\
\hline
\end{tabular}


Table 5 (cont.). Candidate genes coding for putative lipase, caseinase, gelatinase and DNase activities identified in Streptomyces sp. strain AW19M42 draft genome.

\begin{tabular}{llr}
\hline Putative gene & Annotation & Size (aa) \\
\hline STREP_2430 & Deoxyribonuclease/rho motif-related TRAM & 452 \\
STREP_4206 & Deoxyribonuclease & 776 \\
STREP_6678 & Probable endonuclease 4 - Endodeoxyribonuclease & 275 \\
Chitinase & & \\
STREP_2729 & Chitinase, glycosyl hydrolase 18 family & 628 \\
STREP_5817 & Chitinase, glycosyl hydrolase 18 family & 424 \\
STREP_5513 & Carbohydrate-binding CenC domain protein & 577 \\
STREP_3508 & Glycoside hydrolase family protein & 609 \\
STREP_4257 & Putative endochitinase & 350 \\
STREP_6187 & Chitinase, glycosyl hydrolase 19 family & 297 \\
STREP_6188 & Chitinase, glycosyl hydrolase 19 family & 291 \\
Amylase & & \\
STREP_1696 & Glycoside hydrolase starch-binding protein & 573 \\
STREP_5789 & Secreted alpha-amylase & 458 \\
STREP_7405 & Malto-oligosyltrehalose synthase & 834 \\
STREP_1697 & Alpha-1,6-glucosidase, pullulanase-type & 1,774 \\
\hline
\end{tabular}

\section{Conclusion}

The $8 \mathrm{Mb}$ draft genome belonging to Streptomyces sp. strain AW19M42, originally isolated from a marine sea squirt in the sub-Arctic region of Norway has been deposited at ENA/DDBJ/GenBank under accession number CBRG000000000. The isolate was successfully screened for several en-

\section{Acknowledgements}

This work was supported by the Research Council of Norway (Grant no. 192123). We would like to acknowledge Kristin E. Hansen and Seila Pandur for technical assistance during bacterial isolation and nucleic acid extraction. The sequencing service was provided by the Norwegian Sequencing Centre

\section{References}

1. Garrity GM, Holt JG. The Road Map to the Manual. In: Garrity GM, Boone DR, Castenholz RW (eds), Bergey's Manual of Systematic Bacteriology, Second Edition, Volume 1, Springer, New York, 2001, p. 119-169.

2. de Lima Procópio RE, Silva IR, Martins MK, Azevedo JL, Araujo JM. Antibiotics produced by Streptomyces. Braz J Infect Dis 2012; 16:466-471. PubMed http://dx.doi.org/10.1016/j.bjid.2012.08.014 zymatic activities that are applicable in biotechnology and candidate genes coding for the enzyme activities were identified in the genome. Streptomyces sp. strain AW19M42 will serve as a source of functional enzymes and other bioactive chemicals in future bioprospecting projects.

(www.sequencing.uio.no), a national technology platform hosted by the University of Oslo and supported by the "Functional Genomics" and "Infrastructure" programs of the Research Council of Norway and the Southeastern Regional Heal th Authorities.

3. Baltz RH. Streptomyces and Saccharopolysporahosts for heterolog ous expression of secondary metabolite gene clusters. J Ind Microbiol Biotechnol 2010; 37:759-772. PubMed http://dx.doi.org/10.1007/s1 0295-010-0730-9

4. Joshi AP, Deshmukh SS. Streptomycesnucleases. Crit Rev Microbiol 2011; 37:22 7-236. PubMed http://dx.doi.org/10.3109/1040841X.2011.56217 $\underline{3}$ 
5. Sinha S, Tripathi P, Chand S. A new bifunctional chitosanase enzyme from Streptomyces sp. and its application in production of antioxidant chitoolig osaccharides. Appl Biochem Biotechnol 2012; 167:1029-1039. PubMed http://dx.doi.org/10.1007/s12010-012-9546-6

6. Bentley SD, Chater KF, Cerdeno-Tarraga AM, Challis GL, Thomson NR, James KD, Harris DE, Quail MA, Kieser H, Harper D, et al. Complete genome sequence of the model actinomycete Streptomyces coelicolor A3(2). Nature 2002; 417:141-147. PubMed http://dx.doi.org/10.1038/417141a

7. Ohnishi $\mathrm{Y}$, Ishikawa J, Hara H, Suzuki H, Ikenoya M, Ikeda H, Yamashita A, Hattori M, Horinouchi $\mathrm{S}$. Genome sequence of the streptomycinproducing microorganism Streptomyces griseus IFO 13350. I Bacterio/ 2008; 190:4050-4060. PubMed http://dx.doi.org/10.1128//B.00204-08

8. Ikeda $\mathrm{H}$, Ishikawa J, Hanamoto A, Shinose $M$, Kikuchi H, Shiba T, Sakaki Y, Hattori M, Omura $\mathrm{S}$. Complete genome sequence and comparative analysis of the industrial microorg anism Streptomyces avermitilis. Nat Biotechnol 2003; 21:526531. PubMed http://dx.doi.org/10.1038/nbt820

9. Pethick FE, Macfadyen AC, Tang Z, Sangal V, Liu TT, Chu J, Kosec G, Petkovic H, Guo M, Kirby R, et al. Draft genome sequence of the oxytetracycline-producing bacterium Streptomyces rimosus ATCC 10970. Genome Announc 2013; 1:e0006313. PubMed http://dx.doi.org/10.1128/g enomeA.00063-13

10. Erxleben A, Wunsch-Palasis J, Gruning BA, Luzhetska M, Bechthold A, Gunther S. Genome sequence of Streptomyces sp. strain Tu6071. J Bacteriol 2011; 193:4278-42 79. PubMed http://dx.doi.org/10.1128//B.00377-11

11. Wang $X J$, Yan $Y$ J, Zhang B, An J, Wang JJ, Tian J, Jiang L, Chen YH, Huang SX, Yin M, et al. Genome sequence of the milbemycin-producing bacterium Streptomycesbingchenggensis. I Bacteriol 201 0; 192:4526-4527. PubMed http://dx.doi.org/10.1128/JB.00596-10

12. Li F, Jiang $P$, Zheng $H$, Wang $S$, Zhao G, Qin S, Liu Z. Draft genome sequence of the marine bacterium Streptomyces griseoaurantiacus M045, which produces novel manumycin-type antibiotics with a pABA core component. / Bacteriol 2011; 193:3417-3418. PubMed http://dx.doi.org/10.1128//B.05053-11

13. Zhao $X$, Yang T. Draft genome sequence of the marine sediment-derived actinomycete Strepto- myces xingha iens is NRRL B24674T. J Bacteriol

2011; 193:5543. PubMed

http://dx.doi.org/10.1128/JB.05689-11

14. Fan L, Liu Y, Li Z, Baumann HI, Kleinschmidt K, Ye W, Imhoff JF, Kleine M, Cai D. Draft genome sequence of the marine Streptomyces sp. strain PP-C42, isolated from the Baltic Sea. I Bacteriol 2011; 193:3691-3692. PubMed http://dx.doi.org/10.1128//B.05097-11

15. Xiong ZQ, Wang Y. Draft genome sequence of the marine Streptomyces sp. strain AA1529, isolated from the Yellow Sea. J Bacteriol 2012; 194:5474-5475. PubMed http://dx.doi.org/10.1128//B.01247-12

16. Qin S, Zhang H, Li F, Zhu B, Zheng H. Draft genome sequence of marine Streptomyces sp. strain W007, which produces ang ucyclinone antibiotics with a benz[a]anthracene skeleton. J Bacteriol 2012; 194:162 8-1629. PubMed http://dx.doi.org/10.1128//B.06701-11

17. Field D, Garrity G, Gray T, Morrison N, Seleng ut J, Sterk P, Tatusova T, Thomson N, Allen MJ, Angiuoli SV, et al. The minimum information about a genome sequence (MIGS) specification. Nat Biotechnol 2008; 26:541-547. PubMed http://dx.doi.org/10.1038/nbt1360

18. Woese CR, Kandler O, Wheelis ML. Towards a natural system of organisms: proposal for the domains Archaea, Bacteria, and Eucarya. Proc Natl Acad Sci USA 1990; 87:4576-4579. PubMed http://dx.doi.org/10.1073/pnas.87.12.4576

19. Stackebrandt E, Rainey FA, Ward-Rainey NL. Proposal for a New Hierarchic Classification System, Actinobacteriaclassis nov. Int J Syst Bacteriol 1997; 47:479-491.

http://dx.doi.org/10.1099/00207713-47-2-479

20. Zhi XY, Li WJ, Stackebrandt E. An update of the structure and 16S rRNA gene sequence-based definition of higher ranks of the class Actinobacteria, with the proposal of two new suborders and four new families and emended descriptions of the existing higher taxa. Int J Syst Evol Microbiol 2009; 59:589-608. PubMed http://dx.doi.org/10.1099/ijs.0.65780-0

21. Buchanan RE. Studies in the Nomenclature and Classification of the Bacteria II. The Primary Subdivisions of the Schizomycetes. J Bacteriol 1917; 2:155-164. PubMed

22. Skerman VBD, McGowan V, Sneath PHA. Approved Lists of Bacterial Names. Int J Syst Bacteriol 1980; 30:225-420. http://dx.doi.org/10.1099/00207713-30-1-225 
23. Kim SB, Lonsdale J, Seong CN, Goodfellow M. Streptacidiphilus gen. nov., acidophilic actinomycetes with wall chemotype I and emendation of the family Streptomycetaceae (Waksman and Henrici (1943)AL) emend. Rainey et al. 1997. Antonie van Leeuwenhoek 2003; 83:107116. PubMed http://dx.doi.org/10.1023/A:1023397724023

24. Waksman SA, Henrici AT. The Nomenclature and Classification of the Actinomycetes. I Bacteriol 1943; 46:337-341. PubMed

25. Pridham TG, Tressner HD. Genus I. Streptomyces Waksman and Henrici 1943, 339. In: Buchanan RE, Gibbons NE (eds), Bergey's Manual of Determinative Bacteriology, Eighth Edition, The Williams and Wilkins Co., Baltimore, 1974, p. 748829.

26. Witt D, Stackebrandt E. Unification of the genera Streptoverticillium and Streptomyces, and amendation of Streptomyces Waksman and Henrici 1943, 339 AL. Syst Appl Microbiol 1990; 13:361-371. http://dx.doi.org/10.1016/S072 32020(11)80234-1

27. Welling ton EMH, Stackebrandt E, Sanders D, Wolstrup J, Jorgensen NOG. Taxonomic status of Kitasatosporia, and proposed unification with Streptomyces on the basis of phenotypic and 16S rRNA analysis and emendation of Streptomyces Waksman and Henrici 1943, 339AL. Int I Syst Bacteriol 1992; 42:156-160. PubMed http://dx.doi.org/10.1099/00207713-42-1-156

28. Ashburner $M$, Ball CA, Blake JA, Botstein D, Butler H, Cherry JM, Davis AP, Dolinski K, Dwight SS, Eppig JT, et al. Gene ontology: tool for the unification of biology. The Gene Ontology Consortium. Nat Genet 2000; 25:25-29. PubMed http://dx.doi.org/10.1038/75556

29. Bredholt H, Fjaervik E, Johnsen G, Zotchev SB. Actinomycetesfrom sediments in the Trondheim fjord, Norway: diversity and biolog ical activity. Mar Drugs 2008; 6:12-24. PubMed http://dx.doi.org/10.3390/md6010012

30. Hayakawa $\mathbf{M}$, Nonomura $\mathrm{H}$. Humic acid-vitamin agar, a new medium for the selective isolation of soil actinomycetes. J Ferment Technol 1987; 65:501-509. http://dx.doi.org/10.1016/03856380(87)90108-7

31. Lane DJ. 16S/23S rRNA sequencing. In: Stackebrandt E and Goodfellow M (eds.), Nucleic acid techniques in bacterial systematics. John Wiley \& Sons, Chichester, United King dom, 1991, p. 115-175
32. Turner S, Pryer KM, Miao VPW, Palmer JD. Investigating Deep Phylogenetic Relationships among Cyanobacteria and Plastids by Small Subunit rRNA Sequence Analysis. J Eukaryot Microbiol 1999; 46:32 7-338. PubMed http://dx.doi.org/10.1111/j.15507408.1999.tb04612.x

33. Altschul SF, Gish W, Miller W, Myers EW, Lipman DJ. Basic local alignment search tool. J Mol Biol 1990; 215:403-410. PubMed

34. Tamura K, Peterson D, Peterson N, Stecher G, Nei M, Kumar S. MEGA5: molecular evolutionary genetics analysis using maximum likelihood, evolutionary distance, and maximum parsimony methods. Mol Biol Evol 2011; 28:2731-2739. PubMed http://dx.doi.org/10.1093/molbev/msr121

35. Sneath PH, Sokal RR. Numerical taxonomy. Nature 1962; 193:855-860. PubMed http://dx.doi.org/10.1038/193855a0

36. Tamura K, Nei M, Kumar S. Prospects for inferring very large phylog enies by using the neig hborjoining method. Proc Natl Acad Sci USA 2004; 101:11030-11035. PubMed http://dx.doi.org/10.1073/pnas.0404206101

37. Genomics Workbench CLC. 5.0 software package. http://www.clcbio.com.

38. Delcher AL, Bratke KA, Powers EC, Salzberg SL. Identifying bacterial genes and endosymbiont DNA with Glimmer. Bioinformatics 2007;

23:673-679. PubMed http://dx.doi.org/10.1093/bioinformatics/btm009

39. Kanehisa M, Goto S, Sato Y, Furumichi M, Tanabe M. KEGG for integ ration and interpretation of large-scale molecular data sets. Nucleic Acids Res 2012; 40:D109-D1 14. PubMed http://dx.doi.org/10.1093/nar/gkr988

40. Moriya Y, Itoh M, Okuda S, Yoshizawa AC, Kanehisa M. KAAS: an automatic genome annotation and pathway reconstruction server. Nucleic Acids Res 2007; 35:W1 82-W1 85; PubMed. PubMed http://dx.doi.org/10.1093/nar/g km321

41. Dang HY, Zhu H, Wang J, Li TG. Extracellular hydrolytic enzyme screening of culturable heterotrophic bacteria from deep-sea sediments of the Southern Okinawa Trough. World I Microbiol Biotechnol 2009; 25:71-79. http://dx.doi.org/10.1007/s11274-008-9865-5

42. Lee DG, Jeon JH, Jang MK, Kim NY, Lee JH, Lee JH, Kim SJ, Kim GD, Lee SH. Screening and characterization of a novel fibrinolytic 
metalloprotease from a metagenomic library.

Biotechnol Lett 2007; 29:465-472. PubMed

http://dx.doi.org/10.1007/s1 0529-006-9263-8

43. Vermelho $A B$, Meirelles $M N$, Lopes $A$, Petinate $\mathrm{SD}$, Chaia AA, Branquinha $\mathrm{MH}$. Detection of extracellular proteases from microorganisms on agar plates. Mem Inst Oswaldo Cruz 1996; 91:755-

760. PubMed http://dx.doi.org/10.1590/S0074$\underline{02761996000600020}$

44. Usharani TR, Gowda TKS. Cloning of chitinase gene from Bacillus thuringiensis. Indian J Biotechnol 2011; 10:264-269.
45. Mishra S, Behera N. Amylase activity of a starch deg rading bacteria isolated from soil receiving kitchen wastes. Afr J Biotechnol 2008; 7:332 63331.

46. Henne A, Schmitz RA, Bömeke M, Gottschalk G, Daniel R. Screening of environmental DNA libraries for the presence of genes conferring lipolytic activity on Escherichia coli. Appl Environ Microbiol 2000; 66:3113-3116. PubMed http://dx.doi.org/10.1128/AEM.66.7.3113$\underline{3116.2000}$ 